\title{
Change in Future Rainfall Characteristics in the Mekrou Catchment (Benin), from an Ensemble of 3 RCMs (MPI-REMO, DMI-HIRHAM5 and SMHI-RCA4)
}

\author{
Ezéchiel Obada ${ }^{1,2, *}$, Eric Adéchina Alamou ${ }^{2}$, Josué Zandagba ${ }^{1,2}$, Amédée Chabi ${ }^{1,2}$ \\ and Abel Afouda 2,3 \\ 1 International Chair in Mathematical Physics and Applications (ICMPA), University of Abomey-Calavi (UAC), \\ Cotonou 072 B.P 50, Benin; zjosua@yahoo.fr (J.Z.); amedees2005@yahoo.fr (A.C.) \\ 2 Laboratory of Applied Hydrology, University of Abomey-Calavi (UAC), Cotonou 01 BP 4521, Benin; \\ ericalamou@yahoo.fr (E.A.A.); aafouda@yahoo.fr (A.A.) \\ 3 West African Science Service Center on Climate Change and Adapted Land Use (WASCAL), \\ GRP Climate Change and Water Resources, University of Abomey-Calavi (UAC), \\ Abomey-Calavi BP 2008, Benin \\ * Correspondence: e.obada83@yahoo.fr; Tel.: +229-943-350-38
}

Academic Editor: Luca Brocca

Received: 17 January 2017; Accepted: 13 February 2017; Published: 21 February 2017

\begin{abstract}
This study analyzes the impact of climate change on several characteristics of rainfall in the Mekrou catchment for the twenty-first century. To this end, a multi-model ensemble based on regional climate model experiments considering two Representative Concentration Pathways (RCP4.5 and $\mathrm{RCP} 8.5$ ) is used. The results indicate a wider range of precipitation uncertainty (roughly between $-10 \%$ and $10 \%$ ), a decrease in the number of wet days (about $10 \%$ ), an increase (about $10 \%$ ) of the total intensity of precipitation for very wet days, and changes in the length of the dry spell period, as well as the onset and end of the rainy season. The maximum rainfall amounts of consecutive $24 \mathrm{~h}$, $48 \mathrm{~h}$ and $72 \mathrm{~h}$ will experience increases of about $50 \%$ of the reference period. This change in rate compared to the reference period may cause an exacerbation of extreme events (droughts and floods) in the Mekrou basin, especially at the end of the century and under the RCP8.5 scenario. To cope with the challenges posed by the projected climate change for the Mekrou watershed, strong governmental policies are needed to help design response options.
\end{abstract}

Keywords: climate change; precipitation; future projections; trends; extreme events

\section{Introduction}

These last decades, climate change and variability issues have been the main focus of scientists and policy makers around the world. Projected temperatures and precipitation under different scenarios show that climate change will have different impacts in different regions of the globe, with spatio-temporal changes in the occurrence and amounts of rainfall, but usually with an increase in temperature [1-6] in unequal proportions since the Paleolithic period [7,8]. The increase in temperature will affect rainfall and its variability, in particular, droughts and floods $[9,10]$. The impacts of climate change will vary across regions and populations, through space and time, depending on multiple factors, including non-climate stressors and the extent of mitigation and adaptation [11]. According to [12], Africa is one of the most vulnerable continents to climate disturbances due to the diversity of effects of multiple stress and the low adaptive capacity. Recent work in the West African region $[13,14]$, under Representative Concentration Pathway (RCP4.5 and RCP8.5) scenarios 
of climate change projections indicate that continued warming $\left(1-6.5^{\circ} \mathrm{C}\right.$ increase in temperature), and great uncertainty in rainfall (between $-10 \%$ and $10 \%$ ) will be observed in the Sahel until 2100 . According to these authors, the remaining part of West Africa will also experience a more intense extreme climate in the future, but to a lesser extent. It is also reported by previous studies that the rainy and agricultural seasons will become shorter $[15,16]$ while the torrid, arid and semi-arid climate will extend to Sahel $[17,18]$. Such conditions can have important constraints on agricultural activities, water resource management, etc.

Given the alarming regional predictions, it is important to know the precipitation forecasts at local scales in order to propose adaptation and mitigation measures falling within the regional context but with local specificities. It is in this vein that this paper was initiated and aims at studying trends in annual precipitation parameters (annual precipitation amounts, maximum amounts of rainfall in 24 , 48 and 72 consecutive hours, the beginning and end dates of the rainy season, the length of the rainy season, the number of wet days in the year, the length of the dry spell period and total intensity of rainfall for very wet days) in the Mekrou basin over the period 1981-2100.

\section{Study Area, Data and Method}

Our study area is the Mekrou watershed in Kompongou. Covering an area of $5670 \mathrm{~km}^{2}$, it is located in the North of Benin between $1^{\circ} 30^{\prime}$ and $2^{\circ} 15^{\prime}$ East Longitude and $10^{\circ} 20^{\prime}$ and $11^{\circ} 30^{\prime}$ North Latitude. With an elongated shape, it covers three main cities, i.e., Kérou, Kouandé and Péhunco. This watershed belongs to the Benin side of the Niger Basin. The highest point of watershed is Kampuya (639 m) around Kouandé, while the lowest point $(266 \mathrm{~m})$ is located around Kérou and is precisely in the bed of the Mekrou River [19]. The average slope of the stream bed is approximately $2.47 \%$. The soil and the vegetation types encountered in the basin are ferruginous soils on crystalline bedrock, histosols, swamps and fertile gallery forests [20,21]. The rainfall amounts between 1981 and 2014 show that the months of July, August and September are the wettest (Figure 1). The discharge of the Mekrou River at Kompongou varies from $250 \mathrm{~m}^{3} \cdot \mathrm{s}^{-1}$ in September to $0 \mathrm{~m}^{3} \cdot \mathrm{s}^{-1}$ from December to April. The annual mean of flow is about $21 \mathrm{~m}^{3} \cdot \mathrm{s}^{-1}$. High flows occur mostly during August to October.
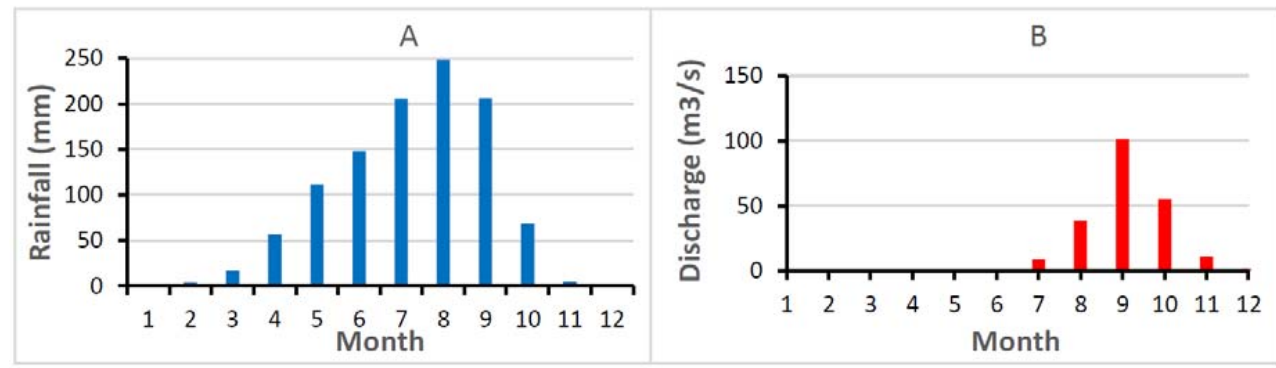

Figure 1. Seasonal variability of rainfall and discharge in the basin (A: Monthly rainfall amounts over 1981-2014; B: Monthly mean of discharge over 2006-2012).

The data used in this study are of two types: observed data and simulated data from Regional Climate Models (RCMs). The two types of data are daily rainfall data. The first were obtained from the National Directorate of Meteorology of Benin. Across the whole watershed, 02 rain gauges are available: these are the Kouandé and Kérou gauges. In addition to these 02 gauges, 12 rain gauges distributed around the basin are also available (Figure 2), resulting in a total of 14 rainfall stations. Over the period 1981-2010, all precipitation stations were functional.

The simulated data are future (RCP4.5 and RCP8.5 scenarios) rainfall projection data of three regional models (SMHI-RCA4, MPI-REMO, DMI-HIRHAM5) obtained from the CORDEX Africa project. Their characteristics are shown in Table 1. The future projections, i.e., the RCP4.5 and RCP8.5 scenarios, are considered over the period from 2011 to 2100. The data bias was corrected using the Empirical Quantile Mapping Method [22]. 


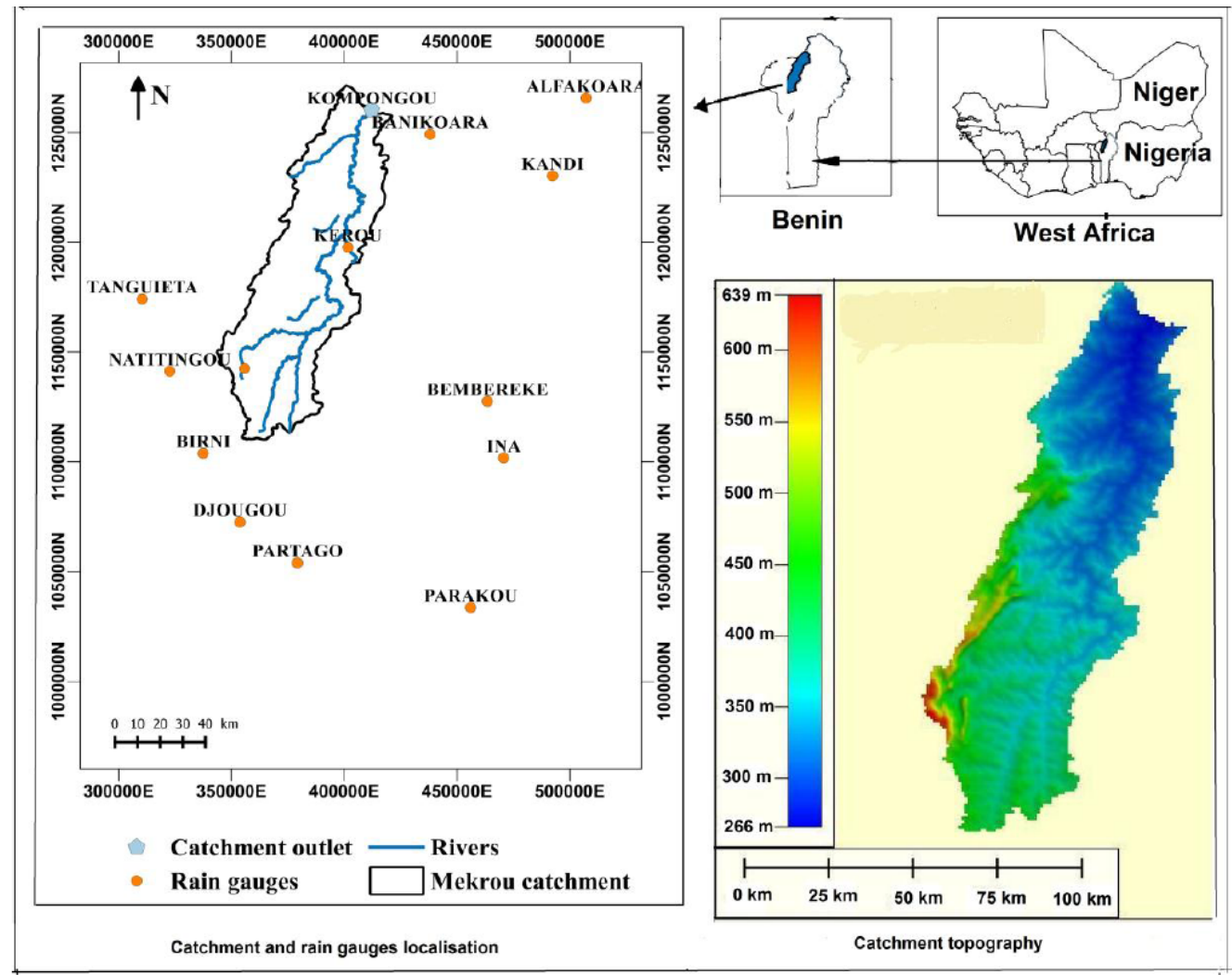

Figure 2. Study area.

Table 1. Main characteristics of the RCMs.

\begin{tabular}{ccccccc}
\hline Model (RCM) & Institution & Driving GCM & $\begin{array}{c}\text { Horizontal } \\
\text { Resolution }\end{array}$ & $\begin{array}{c}\text { No. of Vertical } \\
\text { Levels }\end{array}$ & $\begin{array}{c}\text { Simulation } \\
\text { Period }\end{array}$ & Reference \\
\hline HIRHAM5 & DMI & GFDL-ESM2M & $50 \mathrm{~km}$ & 31 & $1951-2100$ & {$[23]$} \\
REMO & CSC & MPI-ESM-LR & $50 \mathrm{~km}$ & 27 & $1951-2100$ & {$[24]$} \\
RCA4 & SMHI & EC-EARTH & $50 \mathrm{~km}$ & 40 & $1951-2100$ & {$[25]$} \\
\hline
\end{tabular}

The precipitation data from the three RCMs are used as an ensemble that represents the average of the three models. [22] corrected the bias of the precipitation simulated by each of these models and their ensemble with several bias correction methods and concluded that the ensemble of the 3 RCMs better simulated the rainfall than each RCM over the historical period for the same study area. Moreover, according to [11], in Oust Africa, climate models do not converge for the prediction of precipitation. For this, it is better to use a set of climate models in order to reduce the uncertainties of predictions.

The rates of change were calculated by considering four (04) different periods. The first period is the reference period (1981-2010). The three other periods are the projected periods (2011-2040, 2041-2070 and 2071-2100). For each parameter of precipitation and the rainfall stations, the rate of change was calculated using Equation (1).

$$
\text { Change rate }=\frac{\bar{X}_{p}-\bar{X}_{r}}{\bar{X}_{r}} \times 100
$$

where $\bar{X}_{p}$ is the mean of a parameter over the considered projected period, and $\bar{X}_{r}$ is the mean of the same parameter over the reference period. 
The interpolation was performed using the Kriging method. The first step is to construct a spatial structure of each change rate using a semivariogram. The spherical model $\gamma_{\bmod }(h)$ (Equation (2)), where $h$ is the distance between two rain gauges, was adopted to adjust the sample semivariogram. A regular grid point was adopted, and ordinary Kriging, which assumes an unknown mean as well as a second-order stationary process, was implemented.

$$
\gamma_{\text {mod }}(h)=S\left[3 h / 2 a-0.5(h / a)^{3}\right]
$$

where $S$ is the sill and a is the range of the semivariogram.

\section{Results}

\subsection{Mean Values of Study Parameters for Reference Period (1981-2010) in the Mekrou Basin at Kompongou}

The 1970s were characterized by a severe drought in West Africa [26-33]. Over the whole of West Africa, rainfall decreased by $180 \mathrm{~mm}$ compared to the previous period [30]. The following decades were characterized by a recovery of rainfall amounts. According to [15], in the last two decades, not only the total annual precipitation increased, but rainy days occurred more frequently, which led to the partial recovery of precipitation amounts. An increasing trend of annual precipitation was thus observed [13,34-36]. This recovery of precipitation amounts was mainly due to the direct influence of higher levels of anthropogenic greenhouse gases in the atmosphere, as well as changes in the emissions of anthropogenic aerosol precursors [37-40]. Above all, natural variability could also play a significant role in this recovery [41].

In order to quantify future changes, some characteristic parameters of rainfall in the Mekrou basin at the outlet of Kompongou were evaluated for the period from 1981 to 2010 and are considered as reference data for evaluating future rainfall trends. The parameters studied were: the annual rainfall amounts, maximum amounts of rainfall in consecutive 24,48 and $72 \mathrm{~h}$ that can be used as extreme event indicators, the dates of the beginning and end of the rainy season (determined by the method of "anomalous accumulation" proposed by [42], the length of the rainy season, the number of wet days in the year, the length of the dry spell period (maximum number of consecutive days without precipitation or precipitation less than $1 \mathrm{~mm}$ ) that characterizes the occurrence of droughts [43] and total precipitation intensity of very wet days in a year (wet days are considered as the days with precipitation amounts greater than or equal to $1 \mathrm{~mm}$, and very wet days are days with precipitation amounts above the 95th percentile), which measures the occurrence of floods [44].

Despite the low density of rain gauges in the study area, errors related to the interpolation of the different parameters are relatively low and vary between 0 and 0.1 (Figure $3 \mathrm{k}$ ). These low values of the variance show that the number of rain gauges used are sufficient.

The mean annual precipitation amounts over the reference period varies from 900 to $1200 \mathrm{~mm}$ in the basin (Figure 3a). The spatial distribution of annual rainfall amounts shows a reverse direction of change with respect to latitude. There are 3 major areas of precipitation. An area of heavy rainfall (average rainfall of $1100-1200 \mathrm{~mm}$ per year) between $10^{\circ} \mathrm{N}$ and $10.5^{\circ} \mathrm{N}$, a medium rainfall zone in the basin $\left(1000-1100 \mathrm{~mm}\right.$ ) between $10.5^{\circ} \mathrm{N}$ and $11^{\circ} \mathrm{N}$, and an area of low annual rainfall amounts (below $1000 \mathrm{~mm}$ ) between $11^{\circ} \mathrm{N}$ and $11.5^{\circ} \mathrm{N}$. Numbers of wet days in the basin have a spatial distribution almost identical to that of the rainfall amounts. Indeed, in general, the average number of wet days in the basin ranges from 55 to 75 days per year (Figure 3b). Note the existence of three areas with identical variations to those of rainfall amounts. The length of the dry spell period ranges from 140 to 170 days. The length of the drought period also has a spatial distribution that shows the existence of three zones of different drought periods identical to those previously identified (Figure 3c). Here, however, the numbers of consecutive days without rain move in the same direction as the latitude. The mean of the onset dates of the rainy season vary between the 125th day in the year (4 May) and the 141st day (20 May) (Figure 3d). The spatial distribution of the onset of the rainy season 
also shows an evolution depending on the latitude. The more the latitude increases, the more the rainy seasons are slow to start. By contrast, the ends of the rainy season vary little in the basin (274th to 281st) (Figure 3e) and correspond generally to the first week of October. Regarding the lengths of the rainy seasons, they vary between 135 and 155 (Figure 3f). They decrease with increasing latitude. Therefore, the seasons are longer in the South Basin than in the North. The maximum precipitation amounts in consecutive $24 \mathrm{~h}, 48 \mathrm{~h}$ and $72 \mathrm{~h}$ decrease as the latitude increases; they vary between 64 and $80 \mathrm{~mm}$, $75 \mathrm{~mm}$ and $95 \mathrm{~mm}$ and 85 and $110 \mathrm{~mm}$, respectively. The percentages of total precipitation amounts of very wet days compared to total precipitation vary from $57 \%-64 \%$ in the basin. These rates increase with latitude, indicating that the northern basin is more exposed to extreme events such as floods.

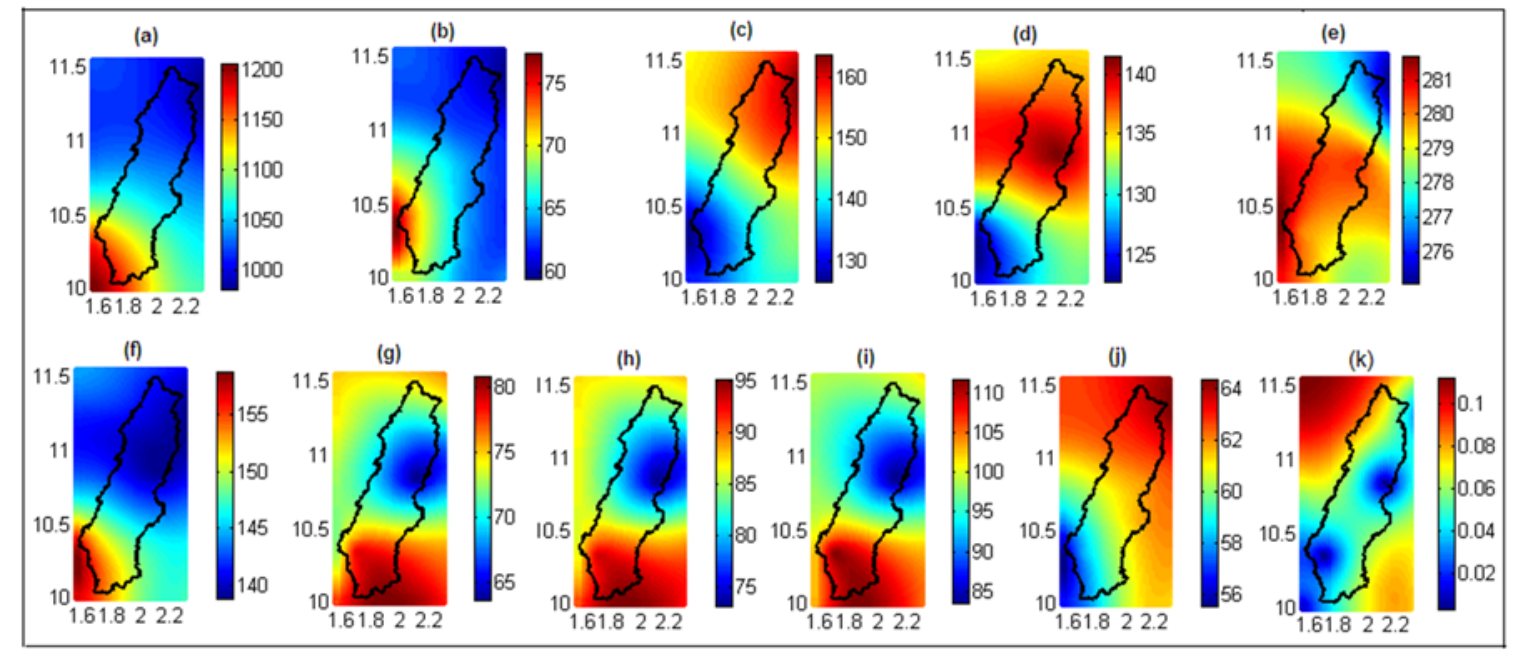

Figure 3. Mean values of rainfall characteristics over the period 1981-2010 (a: annual precipitation amounts (mm); b: number of wet days (day); c: dry spell length (day); d: onset of rainy seasons (Nth day of year); e: end of rainy seasons (Nth day of year); $f$ : length of rainy seasons (day); g: maximum precipitation amounts during 24 consecutive hours $(\mathrm{mm}) ; \mathbf{h}$ : maximum precipitation amounts during 48 consecutive hours (mm); i: maximum precipitation amounts during 72 consecutive hours (mm); $\mathbf{j}$ : total precipitation intensity of very wet days (\%)) k: Kriging variance.

\subsection{Future Changes in Precipitation Characteristics}

\subsubsection{Annual Precipitation Amounts}

Changes in future annual rainfall amounts compared to the reference period are either positive or negative depending on the periods and the scenarios of the greenhouse gas emissions considered. In all cases, these changes are within the range predicted, which is between $-30 \%$ and $30 \%$ of the reference period for West Africa [44], indicating that the projected rainfalls are very uncertain in the region. Changes in the Mekrou basin over the period from 2011 to 2040 show a decrease of $0 \%-5 \%$ of the precipitation amounts compared to the reference period for the RCP4.5 scenario (Figure 4a) and a decrease of $5 \%-12 \%$ for the RCP8.5 scenario (Figure 4e).

The period 2041-2070 is characterized by a net decrease in precipitation amount ( $3 \%-6 \%)$ inside the basin for the RCP4.5 scenario (Figure $4 \mathrm{~b}$ ) and a variation between $-4 \%$ and $5 \%$ for the RCP8.5 scenario (Figure 4f). For both scenarios considered, future projections show an increase in precipitation amounts over the period 2071-2100. These increases vary from 0 to $6 \%$ for the RCP4.5 scenario (Figure $4 \mathrm{c}$ ) and from $4 \%-12 \%$ for the RCP8.5 scenario. The general mean (2011-2100) indicates a decrease in precipitation amounts of $0-4 \%$ for the RCP4.5 scenario (Figure $4 \mathrm{~d}$ ) versus a variation of $-4 \%$ to $4 \%$ for the RCP8.5 scenario (Figure $4 \mathrm{~h}$ ). These results are consistent with those of [13], who predicted rates of change of $-10 \%$ to $10 \%$ for future rainfall in West Africa and those of [15], who stated that precipitation projections are uncertain in West Africa. The spatial variation of projected 
rainfall indicates a deficit of rainfall in the northern half of the basin regardless of the scenario and the period considered (2071-2100), with a growth rate of about $4 \%$.

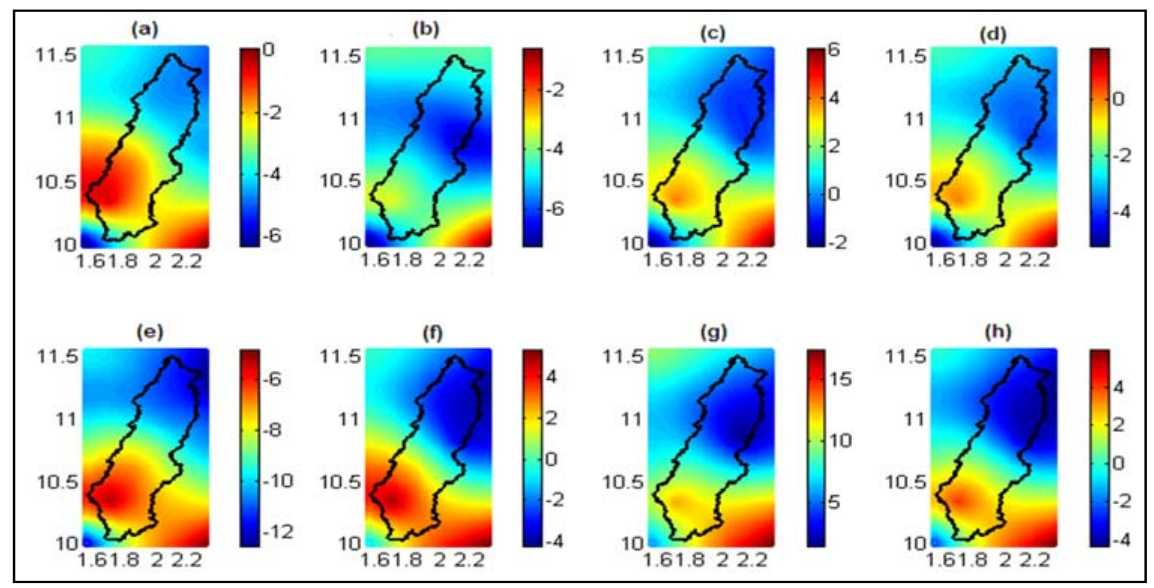

Figure 4. Changes in annual precipitation amounts (\%) compared to the reference period: a: RCP4.5-2011-2040; b: RCP4.5-2041-2070; c: RCP4.5-2071-2100; d: RCP4.5-2011-2100; e: RCP8.5-2011-2040; f: RCP8.5-2041-2070; g: RCP8.5-2071-2100; h: RCP8.5-2011-2100.

\subsubsection{Number of Wet Days}

The average number of wet days according to the RCP4.5 scenario will decrease by about $0 \%-3 \%$ in the South of the basin versus a slight increase of about $0 \%-1 \%$ toward the outlet of the basin for the period 2011-2040 (Figure 5a). However, for the periods of 2041 to 2070 (Figure 5b) and 2071 to 2100 (Figure 5c), the average number of wet days will decrease throughout the basin, by between $4 \%-11 \%$. This indicates a downward trend of wet days in the basin over the period 2011-2100 with an average decrease between $2 \%-7 \%$ (Figure $5 \mathrm{~d}$ ). According to the RCP8.5 scenario, there will be a downward trend in the number of wet days in the watershed regardless of the considered period. Moreover, this decrease would be greater than the one projected by the RCP4.5 scenario. In fact, over the period from 2011 to 2040, the decrease ranges from 5\% to 10\% (Figure 5e). The same range of variation is observed over the period from 2041 to 2070 (Figure 5f). The decrease of number of wet days will be more pronounced over the period from 2071 to 2100 with a decrease between $6 \%$ to $13 \%$ (Figure 5g) compared to the reference period (1981-2010). Over the period from 2011 to 2100, there will be a decrease of $4 \%-10 \%$ (Figure $5 \mathrm{~h}$ ) with respect to the period 1981-2010. We noted that regardless of the period considered and the scenario, the decrease was greater in the northern part of the basin than in the southern part. These results confirm those of [15], with decreases of $7 \%, 3.1 \%$ and $2.1 \%$ for rainy days using the CCLM, RCA and REMO models, respectively, over the period from 2021-2050 in Burkina-Faso.

\subsubsection{Onset of the Rainy Seasons}

The onset dates of the rainy seasons will also experience changes in the basin. Depending on the scenario and the period considered, the future evolution compared to the period of 1981 to 2010 can be positive, negative or both. Over the period from 2011 to 2040, the scenarios RCP4.5 and RCP8.5 (Figure $6 a, e)$ yield a decrease of $0 \%-5 \%$ of the onset of the rainy seasons (rainy season will start one week early) while over the period 2041-2070, the variation compared to the reference period ranges from $-8 \%$ to $0 \%$ for the RCP4.5 scenario (Figure $6 \mathrm{~b}$ ) and $-6 \%$ to $5 \%$ for the RCP 8.5 scenario (Figure $6 \mathrm{f}$ ). Over the period 2071-2100, the RCP4.5 scenario yields an increase of $0 \%-10 \%$ for the onset dates of the rainy season compared to the reference period (Figure $6 \mathrm{c}$ ), while the scenario RCP8.5 yields a variation of $-5 \%$ to $10 \%$ for the dates of the onset of the rainy seasons compared to the period of reference (Figure $6 \mathrm{~g}$ ). For the period 2011 to 2100 , both scenarios project changes varying from $-5 \%$ 
to $5 \%$ (an uncertainty of one week) for the onset dates of the rainy season compared to the reference period (Figure 6d,h). These results indicate that no trend has emerged with respect to the evolution of the onset of rainy seasons but depending on the period, the scenario and the portion of the basin considered, the rainy seasons will begin one week earlier or two weeks later. Similar results were obtained by [15] using 5 different RCMs.

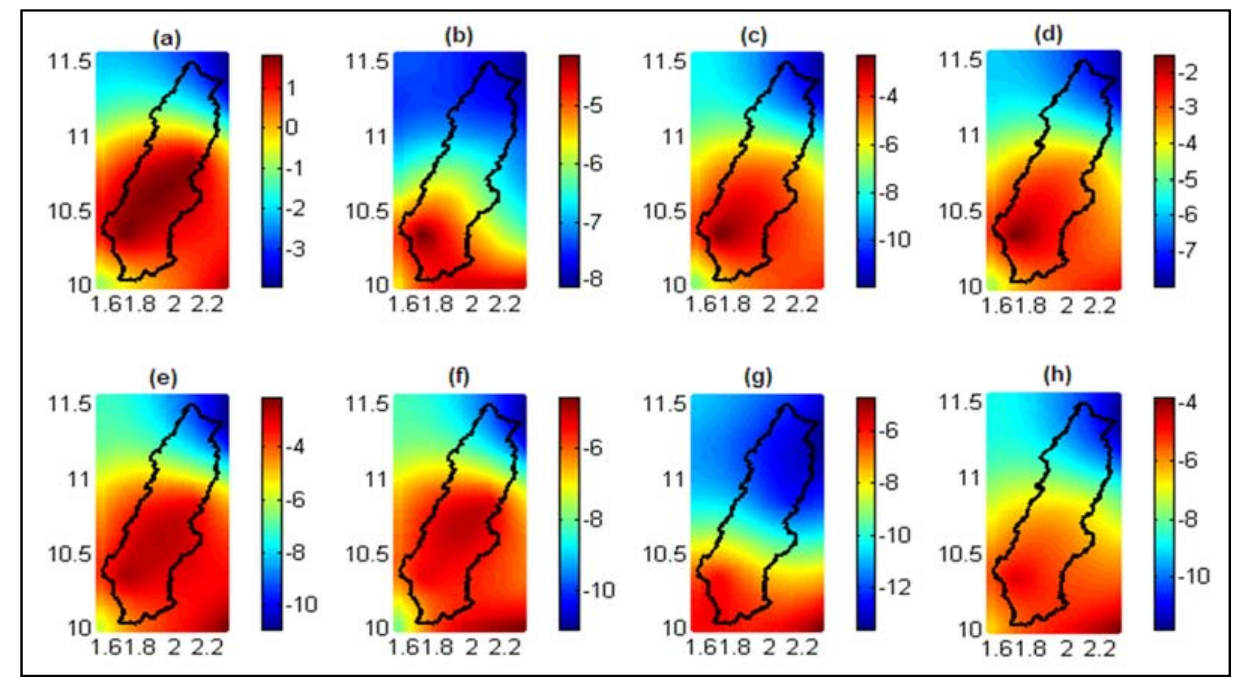

Figure 5. Changes in the number of wet days (\%) compared to the reference period a: RCP4.5-2011-2040; b: RCP4.5-2041-2070; c: RCP4.5-2071-2100; d: RCP4.5-2011-2100; e: RCP8.5-2011-2040; f: RCP8.5-2041-2070; g: RCP8.5-2071-2100; h: RCP8.5-2011-2100.

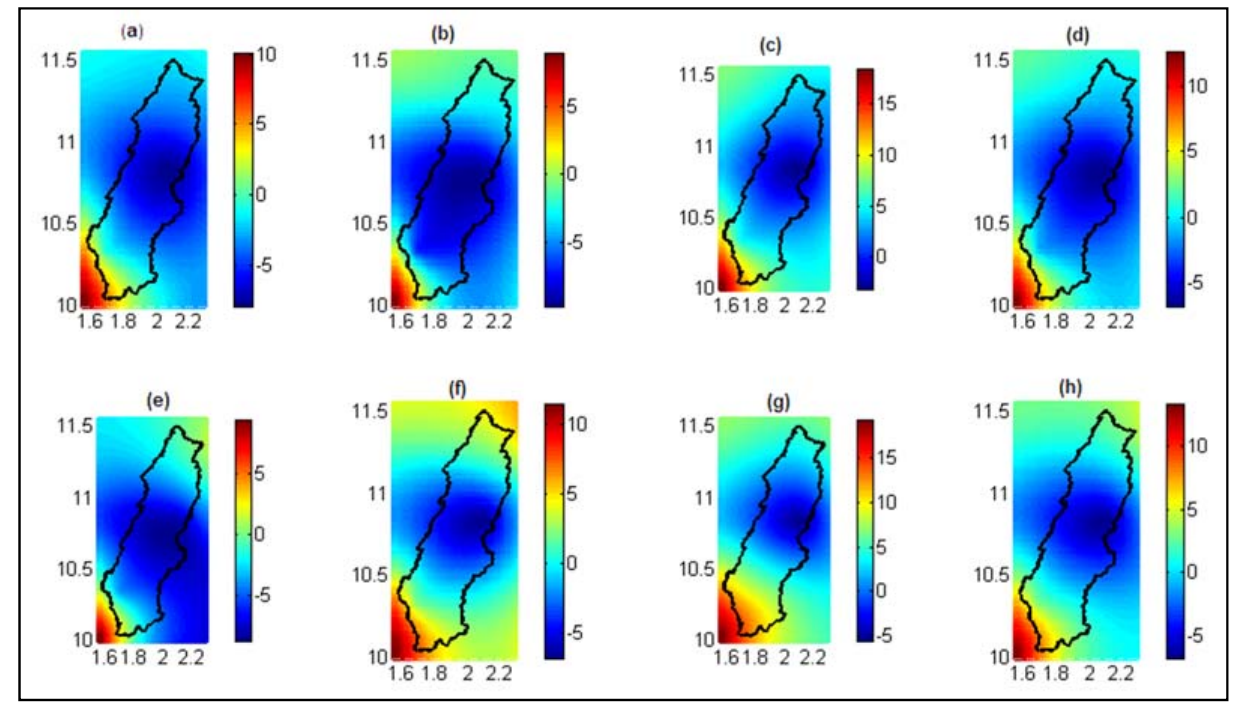

Figure 6. Changes in the onset of the rainy season (\%) compared to the reference period a: RCP4.5-2011-2040; b: RCP4.5-2041-2070; c: RCP4.5-2071-2100; d: RCP4.5-2011-2100; e: RCP8.5-2011-2040; f: RCP8.5-2041-2070; g: RCP8.5-2071-2100; h: RCP8.5-2011-2100.

\subsubsection{End of the Rainy Seasons}

The end dates of the rainy seasons will be earlier compared to reference period, regardless of the scenario and the future period considered. However, these decreases are not important and are $1 \%-2.2 \%$ for the period from 2011 to 2040 under both the RCP4.5 and RCP8.5 scenarios (Figure 7a,e). Over the period 2041-2070, the rates of decrease are in the order of $0.4 \%-1 \%$ for the RCP4.5 scenario (Figure $7 \mathrm{~b}$ ) and 1.5\%-2.5\% for the RCP8.5 scenario (Figure 7f). Over the period 2071-2100, the RCP4.5 
scenario projects a declining rate that ranges between $0 \%$ and $2 \%$ (Figure $7 \mathrm{c}$ ) versus the rate of decrease of $0.5 \%-3 \%$ for the RCP8.5 scenario compared to the values of the reference period (Figure $7 \mathrm{~g}$ ). Over the period from 2011 to 2100 , the RCP4.5 scenario predicts earlier end datesof the rainy season, which range from $0.6 \%-1.6 \%$ (Figure $7 \mathrm{~d}$ ), whereas for the RCP8.5 scenario, these decreases are between $1 \%$ and $2.7 \%$ (Figure $7 \mathrm{~h}$ ) with respect to the reference period values. These results indicate that the season will end earlier and will probably decrease the length of the rainy seasons. These results are in contrast to those of [15], who predicted an later end date of the rainy season for five models used in Burkina-Faso.

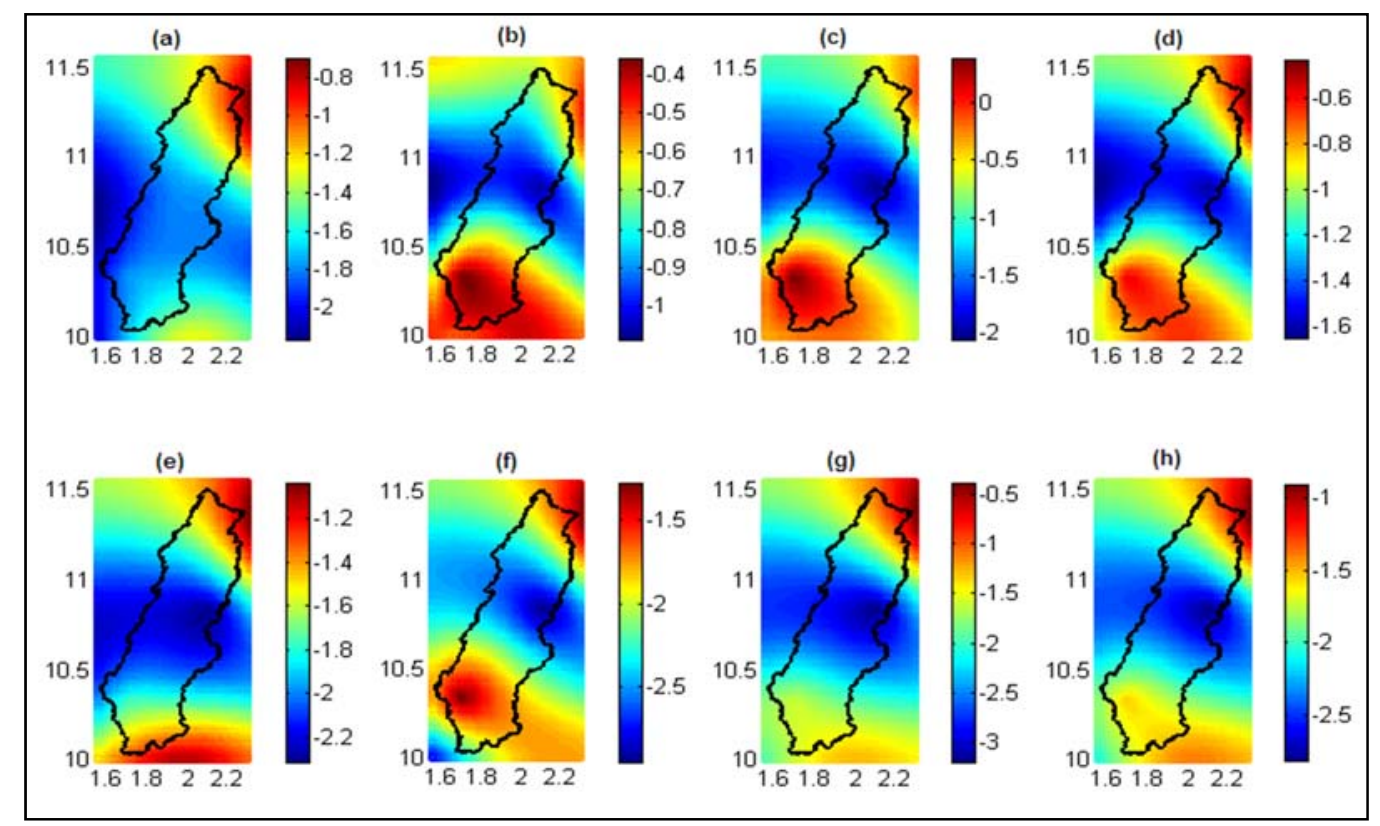

Figure 7. Changes in the end of the rainy season (\%) compared to the reference period a: RCP4.5-2011-2040; b: RCP4.5-2041-2070; c: RCP4.5-2071-2100; d: RCP4.5-2011-2100; e: RCP8.5-2011-2040; f: RCP8.5-2041-2070; g: RCP8.5-2071-2100; h: RCP8.5-2011-2100.

\subsubsection{Length of the Rainy Seasons}

The length of the rainy seasons will experience changes in the future. These changes will vary from one period to another, and their changes compared to the reference period appear to be related to the greenhouse gas emission scenarios (Figure 8). Over the period from 2011 to 2040, both the RCP4.5 and RCP8.5 scenarios predict changes that are both negative and positive in the lengths of the rainy seasons compared to the reference period (Figure 8a,e). These changes are almost identical for both scenarios and generally range from $-5 \%$ to $3 \%$. Over the period 2041-2070, the RCP 4.5 scenario projects an increase of $0 \%-6 \%$ in the lengths of the rainy seasons (Figure $8 \mathrm{~b}$ ) compared to the reference period, while the RCP8.5 scenario projects a decrease in the length of the rainy seasons (between $0 \%-8 \%$; Figure $8 \mathrm{f}$ ). Large decreases in the length of the rainy seasons will be observed in the period from 2071 to 2100 . These decreases vary from $2 \%$ to $10 \%$ for the RCP4.5 scenario (Figure $8 \mathrm{c}$ ). They are more pronounced for the RCP8.5 scenario and are between $3 \%$ and $15 \%$ (Figure $8 \mathrm{~g}$ ) with respect to the reference period values. Generally, the RCP4.5 scenario shows variations ranging from $-6 \%$ to $3 \%$ (Figure $8 \mathrm{~d}$ ) for the length of the rainy seasons in the period from 2011 to 2100 compared to the reference period, while the scenario RCP 8.5 indicates decreases of $0 \%-8 \%$ (Figure $8 \mathrm{~h}$ ). For the period 2011-2040, there is uncertainty in the trend of the change in the length of the rainy seasons in the basin; it is clear that for the following periods there will be a net decrease in the length of the rainy seasons, especially for RCP8.5 scenario. 


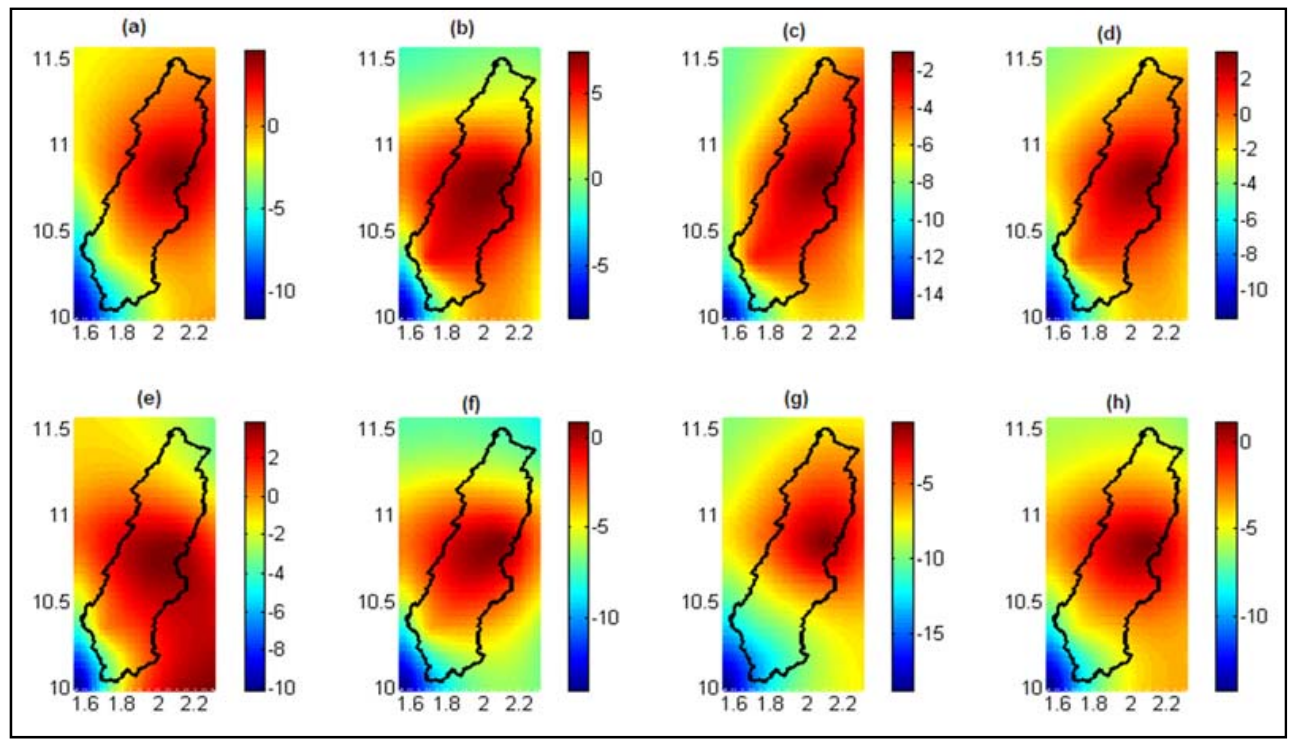

Figure 8. Changes in the length of the rainy season (\%) compared to the reference period: a: RCP4.5-2011-2040; b: RCP4.5-2041-2070; c: RCP4.5-2071-2100; d: RCP4.5-2011-2100; e: RCP8.5-2011-2040; f: RCP8.5-2041-2070; g: RCP8.5-2071-2100; h: RCP8.5-2011-2100.

\subsubsection{Length of Dry Spells}

Figure 9 shows that there will be an increase in the length of dry spells irrespective of the period and the scenario considered. In fact, both the RCP4.5 and RCP8.5 scenarios predict an increase of $0 \%-10 \%$ in the length of the dry spells in the period from 2011 to 2040 compared to the reference period (Figure 9a,e). In the period 2041-2070, there will be an accentuation of the increase in the length of the dry spells compared to the reference period. This increase ranges between $4 \%$ and $12 \%$ for the RCP4.5 scenario (Figure 9b) versus $4 \%$ to $15 \%$ for the RCP 8.5 scenario (Figure $9 \mathrm{f}$ ). In the period from 2070 to 2100 , these increases range from 5\% to 9\% for the RCP4.5 scenario (Figure 9c) versus $0 \%$ to $10 \%$ for the RCP8.5 scenario (Figure $9 \mathrm{~g}$ ). These results are in line with those of other authors who also predict an increasing trend in the lengths of dry spells in the West Africa area [13,15].

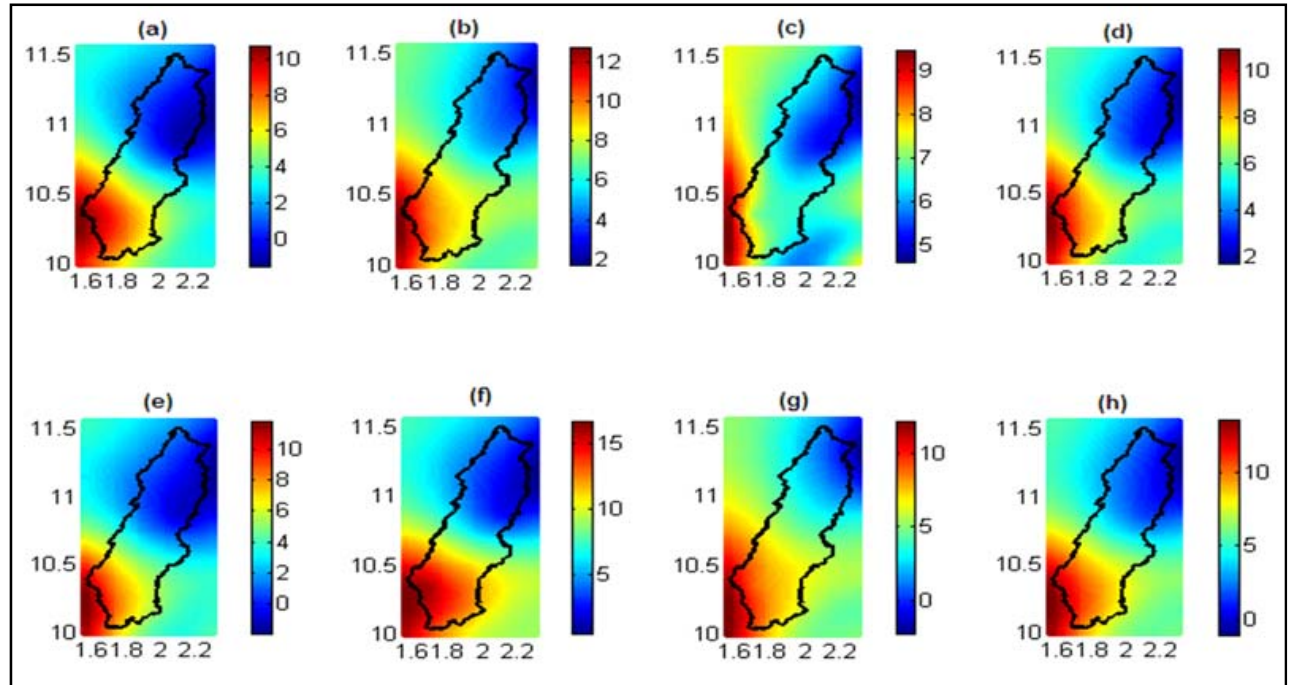

Figure 9. Changes in the lengths of the dry spells (\%) compared to the reference period: a: RCP4.5-2011-2040; b: RCP4.5-2041-2070; c: RCP4.5-2071-2100; d: RCP4.5-2011-2100; e: RCP8.5-2011-2040; f: RCP8.5-2041-2070; g: RCP8.5-2071-2100; h: RCP8.5-2011-2100. 


\subsubsection{Total Precipitation Intensity of Very Wet Days}

The total precipitation intensity of very wet days will also experience changes in future years depending on the scenario considered. In general (period of 2011-2100), the RCP4.5 scenario projects increases of $3 \%-5 \%$ (Figure 10d) for the total precipitation intensity of very wet days compared to the reference period. These increases are more important under the RCP 8.5 scenario and vary from $6 \%-9 \%$ for the same period (Figure 10h). However, when one considers the different sub-periods, we notice that over the period from 2011 to 2040 and for the RCP4.5 scenario, the rate of change in the total precipitation intensity of the very wet days is very low and ranges from $-1 \%$ to $1 \%$ (Figure 10a). For the same period, the RCP8.5 scenario projects an increase of $2 \%-5 \%$ compared to the reference period (Figure 10e). In the next period (2041-2070), there will be an increase in the total precipitation intensity of very wet days compared to the previous period. These intensifications result in an increase of $5 \%-7 \%$ (Figure 10b) of total precipitation intensity of very wet days relative to the reference period for the RCP4.5 scenario and 7\%-10\% for the RCP8.5 scenario (Figure 10f). The intensity of total precipitation for very wet days in the period 2071-2100 will be the highest in the entire period from 1981-2100. In fact, the RCP4.5 scenario projects growth rates of 4\%-9\% (Figure 10C) compared to the reference period, while the RCP8.5 scenario projects rates of $8 \%-12 \%$, which are the highest across periods and scenarios. The increase in the total precipitation intensity of very wet days confirms the trend of exacerbation of extreme events in West Africa announced by [8].

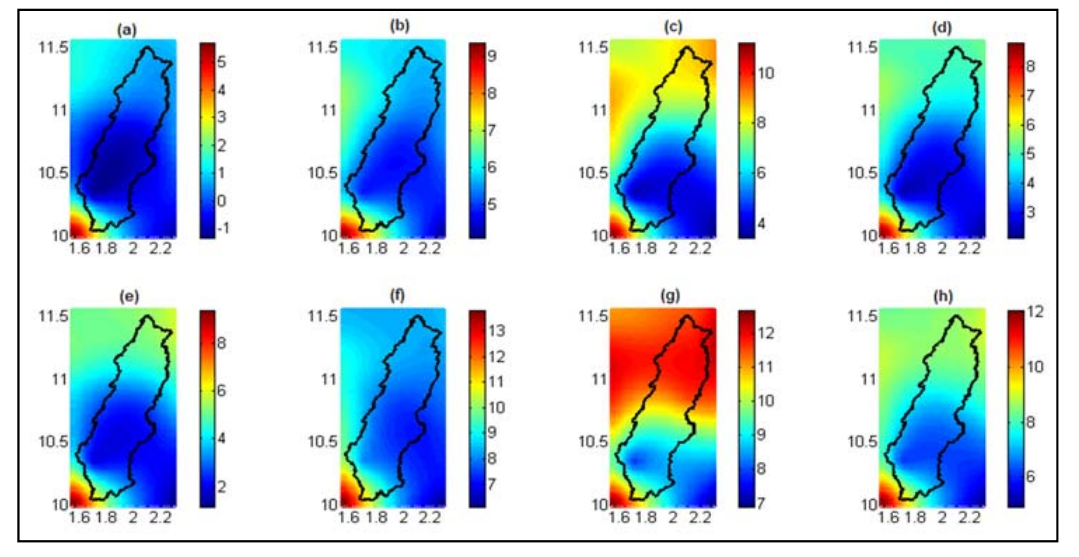

Figure 10. Changes in the total precipitation intensity of very wet days (\%) compared to the reference period: a: RCP4.5-2011-2040; b: RCP4.5-2041-2070; c: RCP4.5-2071-2100; d: RCP4.5-2011-2100; e: RCP8.5-2011-2040; f: RCP8.5-2041-2070; g: RCP8.5-2071-2100; h: RCP8.5-2011-2100.

With the objective of assessing the occurrence and intensity of extreme events, changes in the maximum precipitation amounts in 24,48 and 72 consecutive hours per year were studied.

\subsubsection{Maximum Precipitation Amounts During 24 Consecutive Hours}

In general, the two scenarios project an upward trend of daily maximum precipitation amounts. The average maximum daily precipitation amounts over the period of 2011-2100 show increases ranging from 5 to $15 \%$ compared to the reference period for the RCP4.5 scenario (Figure 11d) and $22 \%-30 \%$ for the RCP8.5 scenario (Figure 11h). Irrespective of the scenario considered, the maximum daily precipitation increases over time, i.e, $0 \%-7 \%$ for the period $2011-2040$ (Figure 11a), $0 \%-15 \%$ for the period 2041-2070 (Figure 11b) and 10\%-25\% for the period 2071-2100 (Figure 11c) compared to the period 1981-2010 for RCP4.5 scenario. For the RCP8.5 scenario, the increase in maximum daily precipitation amount compared to the reference period is higher than that projected by the RCP4.5 scenario and is about $4 \%-11 \%$ for the period $2011-2040$ (Figure 11e), $20 \%-35 \%$ for the period $2041-2070$ (Figure 11f) and 35\%-45\% for the period 2071-2100 (Figure 11g). This indicates an intensification of extreme rainy events in the basin, which may increase the occurrence of floods. 


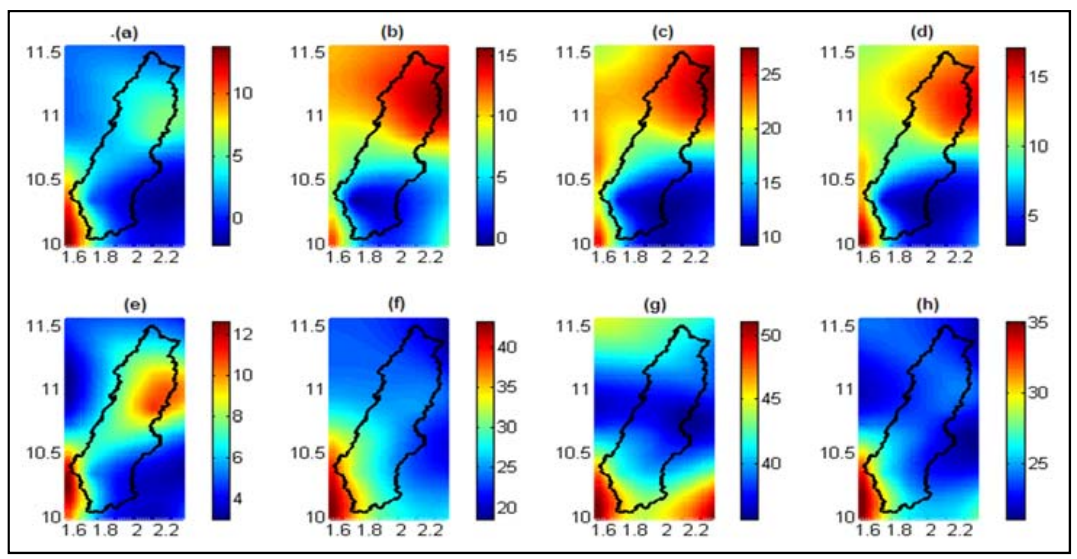

Figure 11. Changes in the maximum precipitation amounts during 24 consecutive hours (\%) compared to the reference period: a: RCP4.5-2011-2040; b: RCP4.5-2041-2070; c: RCP4.5-2071-2100; d: RCP4.5-2011-2100; e: RCP8.5-2011-2040; f: RCP8.5-2041-2070; g: RCP8.5-2071-2100; h: RCP8.5-2011-2100.

\subsubsection{Maximum Precipitation Amounts During 48 Consecutive Hours}

The maximum precipitation amounts during 48 consecutive hours also showed an upward trend over the period 2011-2100 for both the RCP4.5 and RCP8.5 scenarios. The increase rates are $13 \%-31 \%$ for the RCP4.5 scenario compared to the values of the reference period (Figure 12d). For scenario RCP8.5, the increase rates vary from 34\% to 41\% (Figure 12h). For the periods 2011-2040 and 2041-2070, the change rate in the maximum precipitation amounts during 48 consecutive ours projected by the RCP4.5 scenario are identical and represent an increase of about $8 \%-25 \%$ (Figure 12a,b) compared to the reference period, but for the period 2071-2100, these rates reach $22 \%-42 \%$ (Figure 12c). With respect to the projections of the RCP8.5 scenario, the rates of increase of the maximum precipitation amounts during $48 \mathrm{~h}$ compared to the reference period are considerably higher than those projected by the RCP4.5 scenario. In fact, values of $12 \%-28 \%$ will be reached for the period 2011-2040 (Figure 12e); the projections of the maximum precipitation amounts during 48 consecutive hours reach increase rates of 30\%-50\% (for 2041-2070) (Figure 12f) and 50\%-60\% (for 2070-2100) (Figure 12g) relative to the reference period. It appears from these results that an increased frequency of flooding could occur in the basin.

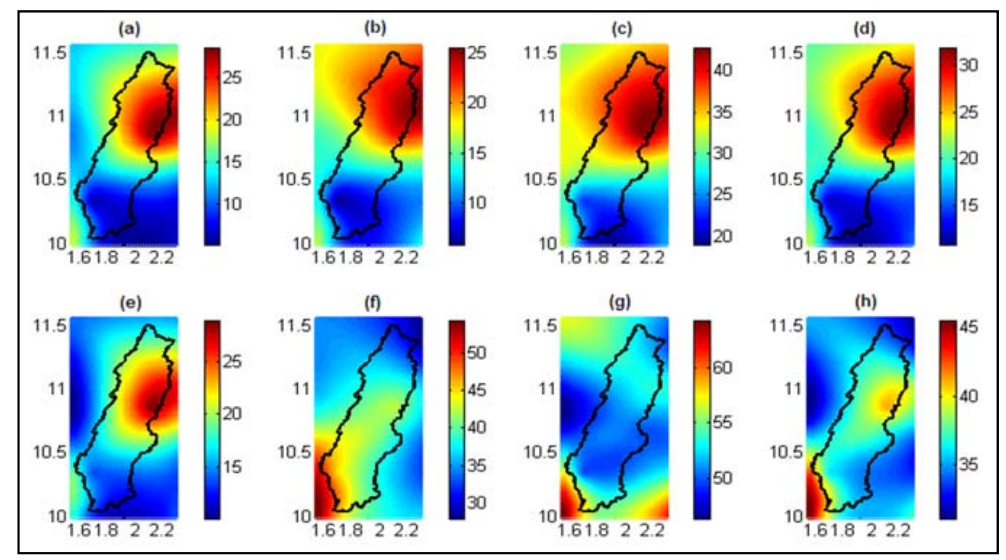

Figure 12. Changes in the maximum precipitation amounts during 48 consecutive hours (\%) compared to the reference period: a: RCP4.5-2011-2040; b: RCP4.5-2041-2070; c: RCP4.5-2071-2100; d: RCP4.5-2011-2100; e: RCP8.5-2011-2040; f: RCP8.5-2041-2070; g: RCP8.5-2071-2100; h: RCP8.5-2011-2100. 


\subsubsection{Maximum Precipitation Amounts during 72 Consecutive Hours}

Similar to the maximum precipitation amounts for 24 and 48 consecutive hours, projections of precipitation amounts during 72 consecutive hours also show an increasing trend over the period 2011-2100. This trend is characterized by an increase in maximum precipitation amounts for 72 consecutive hours of $5 \%-25 \%$ for the medium scenario of greenhouse gas emissions (Figure 13d) and of $22 \%-34 \%$ for the high scenario of greenhouse gas emissions (Figure 13h) compared to the reference period. Over the period 2011-2040, the two scenarios (RCP4.5 and RCP8.5) indicate an increase of about 3\%-20\% compared to the reference period (Figure 13a,e). The northern area of the basin is the most exposed to these changes, with rates reaching 20\%. In the period 2041-2100, a large difference is observed between the projections of the two scenarios. The RCP4.5 scenario indicates changes of $-5 \%$ to $20 \%$ over the period from 2041 to 2070 (Figure 13b) with a decrease trend in the southern part of the basin versus an increasing trend towards the North. For the same scenario, the projections of 2071-2100 indicate high increases (20\%-41\%) of maximum precipitation amounts of 72 consecutive hours compared to the reference period (Figure 13c). The northern area of the basin also has the highest rates of increase, reaching $40 \%$. The RCP8.5 scenario projections show alarming increases for the maximum precipitation amounts during 72 consecutive $h$ during the period from 2041 to 2100 throughout the watershed. These increases are in the range of $25 \%-35 \%$ over the period $2041-2070$ (Figure 13f) and $38 \%-50 \%$ for the $2071-2100$ period. These strong increase rates have certainly resulted in an increase in flooding frequency.

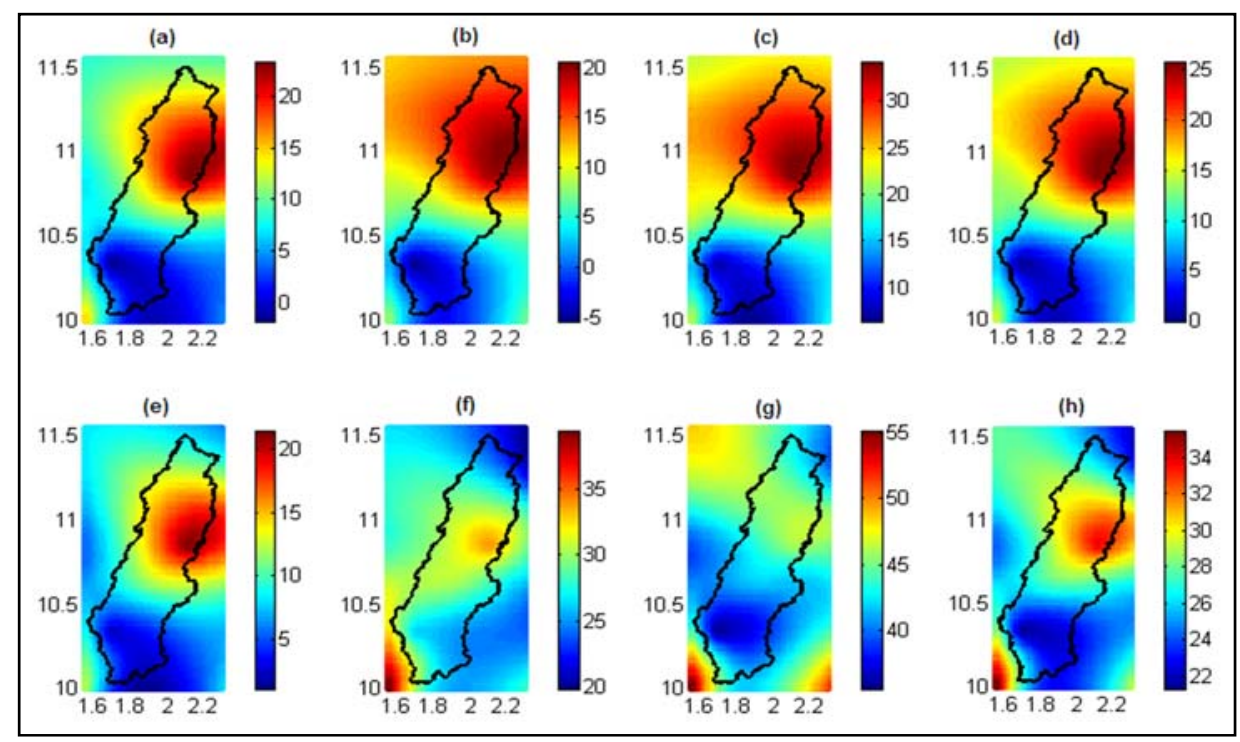

Figure 13. Changes in the maximum precipitation amounts during 72 consecutive hours (\%) compared to the reference period: a: RCP4.5-2011-2040; b: RCP4.5-2041-2070; c: RCP4.5-2071-2100; d: RCP4.5-2011-2100; e: RCP8.5-2011-2040; f: RCP8.5-2041-2070; g: RCP8.5-2071-2100; h: RCP8.5-2011-2100.

\section{Discussion}

The structure of future projections of rainy seasons based a set of 3 Regional Climate Models (MPI-REMO, DMI-HIRHAM5 and SMHI-RCA4) for RCP4.5 and RCP8.5 scenarios was studied in this paper through a set of ten (10) characteristics of precipitation. The impacts of climate change on the annual precipitation amounts in the basin are quite varied depending on the period and the scenario, similar to many studies in the West African region [13-15,45-47]. For the two (2) scenarios and the period 2011-2070, a decrease in annual rainfall amounts reaching $12 \%$ is projected versus an increase of around 10\% for the 2071-2100 period. This indicates that in the coming decades, the basin could 
be exposed to a long dry period that can lead to declining agricultural production, food insecurity, famine, rural migration, etc.

The number of wet days and the rainy season length gradually decrease from 2011 to 2100 . These simultaneous decreases in the two (02) parameters will certainly have great consequences for agriculture, which is essentially dependent on rainfall in the region. As for the occurrence and intensification of extreme events in the basin, the simultaneous increase trends related to total precipitation intensity of very wet days and maximum precipitation amounts for 24,48 and 72 consecutive hours constitute evidence of a possible increase in the frequency and magnitude of floods in the future. Otherwise, the increase trend in the length of dry spells is also an index of exacerbation of drought in the basin. In short, the risk of exacerbation of extreme events exists in the future (drought, flood, food insecurity, rural migration, etc.). This would be the result of future anthropogenic emissions of greenhouse gases [16,48-52]. It has been established that the aggravation of extreme events intensifies local hydrological cycles [53-55]. As established for the West African region, the Mekrou basin will experience changes in climate that will impact agriculture, water resources, and ecosystems, which will affect the rural population, as well as those with urban lifestyles.

\section{Conclusions}

West Africa is already facing the consequences of climate change. In this paper, future trends of some precipitation characteristics of multi-RCMs under projections (2011-2100) of the RCP4.5 and RCP8.5 scenarios are examined in relation to the observations of the period 1981-2010 in the Mekrou basin at the Kompongou outlet. The results confirm the expected projections in the West African region with regards to annual rainfall amounts (ranging from $-10 \%$ to $10 \%$ ), the number of wet days (decrease of up to $10 \%$ ), total precipitation intensity of very wet days (increase of around $10 \%$ ), the length of the dry spells (increase up to $10 \%$ ) and the dates of onset and ending of the rainy seasons. The maximum rainfall amounts during 24, 48 and 72 consecutive hours will experience increases of about $50 \%$ compared to the reference period. These rates of change may result in exacerbation of extreme events (droughts and floods) in the Mekrou basin.

Author Contributions: Ezéchiel Obada, Eric Adéchina Alamou, Josué Zandagba, Amédée Chabi and Abel Afouda designed the study, developed the methodology and wrote the manuscript. Ezéchiel Obada performed the field work, collected the data and conducted the computer analysis with Josué Zandagba and Amédée Chabi. Eric Adéchina Alamou and Abel Afouda supervised this part of the work.

Conflicts of Interest: The authors declare no conflict of interest.

\section{References}

1. Barrios, S.; Ouattara, B.; Strobl, E. The impact of climatic change on agricultural production: Is it different for Africa? Food Policy 2008, 33, 287-298. [CrossRef]

2. Dang, H.; Gillett, N.P.; Weaver, A.J.; Zwiers, F.W. Climate change detection over different land surface vegetation classes. Int. J. Climatol. 2007, 27, 211-220. [CrossRef]

3. IPCC. Climate Change 2001: The Climate Change. Contribution of the Working Group I to the Third Asseesment Report of the Intergoummental Panel on Climate Change; Cambridge University Press: Cambridge, UK, 2001.

4. Meissner, K.; Weaver, A.; Matthews, H.; Cox, P. The role of land surface dynamics in glacial inception: A study with the UVic Earth System Model. Clim. Dyn. 2003, 21, 515-537. [CrossRef]

5. Snyder, P.; Delire, C.; Foley, J. Evaluating the influence of different vegetation biomes on the global climate. Clim. Dyn. 2004, 23, 279-302. [CrossRef]

6. Tarhule, A. Damaging rainfall and flooding: The other Sahel hazards. Clim. Change 2005, 72, 355-377. [CrossRef]

7. Karl, T.R.; Arguez, A.; Huang, B.; Lawrimore, J.H.; Menne, M.J.; Peterson, T.C.; Vose, R.S.; Zhang, H.M. Possible artifacts of data biases in the recent global surface warming hiatus. Science 2015, 348, 1469-1472. [CrossRef] [PubMed] 
8. IPCC. Climate Change 2013: The Physical Science Basis. Contribution of Working Group I to the Fifth Assessment Report of the Intergovernmental Panel on Climate Change; Cambridge University Press: Cambridge, UK; New York, NY, USA, 2013.

9. Zwiers, F.W.; Alexander, L.V.; Hegerl, G.C.; Knutson, T.R.; Kossin, J.; Naveau, P.; Nicholls, N.; Schär, C.; Seneviratne, S.I.; Zhang, X. Challenges in estimating and understanding recent changes in the frequency and intensity of extreme climate and weather events. In Climate Science for Serving Society: Research, Modeling and Prediction Priorities; Springer: Berlin, Germany, 2013.

10. Giorgi, F.; Coppola, E.; Raffaele, F. A consistent picture of the hydroclimatic response to global warming from multiple indices: Models and observations. J. Geophys. Res. Atmos. 2014, 119. [CrossRef]

11. IPCC. Summary for Policymakers. In Climate Change 2014: Impacts, Adaptation, and Vulnerability. Contribution of Working Group II to the Fifth Assessment Report of the Intergovernmental Panel on Climate Change; Cambridge University Press: Cambridge, UK; New York, NY, USA, 2014.

12. IPCC. Climate Change 2007-Synthesis Report. Intergovernmental Panel on Climate Change; Cambridge University Press: Cambridge, UK, 2007.

13. Sylla, M.B.; Nikiema, P.M.; Gibba, P.; Kebe, I.; Klutse, N.A.B. Climate Change over West Africa: Recent Trends and Future Projections. In Adaptation to Climate Change and Variability in Rural West Africa; Springer: Basel, Switzerland, 2016.

14. Tall, M.; Sylla, M.B.; Diallo, I.; Pal, J.S.; Faye, A.; Mbaye, M.L.; Gaye, A.T. Projected impact of climate change in the hydroclimatology of Senegal with a focus over the Lake of Guiers for the twenty-first century. Theor. Appl. Clim. 2016. [CrossRef]

15. Ibrahim, B.; Karambiri, H.; Polcher, J.; Yacouba, H.; Ribstein, P. Changes in rainfall regime over Burkina Faso under the climate change conditions simulated by 5 regional climate models. Clim. Dyn. 2014, 42, 1363-1381. [CrossRef]

16. Cook, K.H.; Vizy, E.K. Impact of climate change on mid-twenty-first century growing seasons in Africa. Clim. Dyn. 2012, 39, 2937-2955. [CrossRef]

17. Elguindi, N.; Grundstein, A.; Bernardes, S.; Turuncoglu, U.; Feddema, J. Assessment of CMIP5 global model simulations and climate change projections for the 21st Century using a modified Thornthwaite climate classification. Clim. Chang. 2014, 122, 523-538. [CrossRef]

18. Sylla, M.B.; Elguindi, N.; Giorgi, F.; Wisser, D. Projected robust shift of climate zones over West Africa in response to anthropogenic climate change for the late 21st century. Clim. Chang. 2016, 134, 241-253. [CrossRef]

19. Gaba, O.U.C.; Biao, I.E.; Alamou, A.E.; Afouda, A. An Ensemble Approach Modelling to Assess Water Resources in the Mékrou Basin, Benin. IJCET 2015, 3, 22-32.

20. GLEauBe. Etude Portant État Des Lieux et Gestion de L'information sur les Ressources en eau Dans le Bassin de la Mékrou; Rapport Technique: Cotonou, Benin, 2002; p. 104.

21. Benoit, M. Statut et usages du sol en périphérie du parc national du " $w$ " du Niger. Tome 1 Contribution à l'étude du milieu naturel et des ressources végétales du canton de Tamou et du Parc du "W"; ORSTOM: Bondy, France, 1998.

22. Obada, E.; Alamou, A.E.; Zandagba, E.J.; Biao, I.E.; Chabi, A.; Afouda, A. Comparative study of seven bias correction methods applied to three Regional Climate Models in Mekrou Catchment (Benin, West Africa). IJCET 2016, 6, 1831-1840.

23. Christensen, O.B.; Drews, M.; Christensen, J.H. The HIRHAM regional climate model version 5. Available online: http:/ / orbit.dtu.dk/fedora/objects/orbit:118724/datastreams/file_8c69af6e-acfb-4d1aaa53-73188c001d36/content (accessed on 15 February 2017).

24. Jacob, D.; Bärring, L.; Christensen, O.B.; Christensen, J.H.; Hagemann, S.; Hirschi, M.; Kjellström, E.; Lenderink, G.; Rockel, B.; Schär, C.; et al. An inter-comparison of regional climate models for Europe: Design of the experiments and model performance. Clim. Chang. 2007, 81,31-52. [CrossRef]

25. Samuelsson, P.; Jones, C.G.; Wille’n, U.; Ullerstig, A.; Gollvik, S.; Hansson, U.; Kjellström, E.; Nikulin, G.; Wyser, K. The Rossby Centre regional climate model RCA3: model description and performance. Tellus. A 2011, 63, 4-23. [CrossRef]

26. Servat, E.; Paturel, J.E.; Kouamé, B.; Lubès-Niel, H.; Ouedraogo, M.; Masson, J.M. Climatic variability in humid Africa along the Gulfe of Guinea. Part I: Detailed analysis of the phenomenon in Côte d'Ivoire. J. Hydrol. 1997, 191, 1-15. [CrossRef] 
27. Servat, E.; Paturel, J.E.; Kouamé, B.; Travaglio, M.; Ouédraogo, M.; Boyer, J.F.; Lubès-Niel, H.; Fritsch, J.M.; Masson, J.M.; Marieu, B. Identification, caractérisation et conséquences d'une variabilité hydrologique en Afrique de l'Ouest et centrale. IAHS Publ. 1998, 252, 323-337.

28. Servat, E.; Paturel, J.E.; Lubès-Niel, H.; Kouamé, B.; Masson, J.M.; Travaglio, M.; Marieu, B. De différents aspects de la variabilité de la pluviométrie en Afrique de l'ouest et centrale non sahélienne. Rev. Sci. Eau 1999, 12, 363-387. [CrossRef]

29. Ardoin, S.; Lubès-Niel, H.; Servat, E.; Dezetter, A.; Boyer, J.F. Analyse de la persistance de la sécheresse en Afrique de l'Ouest: Caractérisation de la situation de la décennie 1990. IAHS Publi. 2003, 278, 223-228.

30. Vissin, E.W.; Boko, M.; Perard, J.; Houndenou, C. Recherche de ruptures dans les séries pluviométriques et hydrologiques du bassin béninois du fleuve Niger (Bénin, Afrique de l'Ouest). Assoc. Int. Clim. 2003, 15, 368-376.

31. Ardoin, S. Variabilité hydroclimatique et impacts sur les ressources en eau de grands bassins hydrographiques en zone soudano-sahélienne. Thèse de Doctorat, Université de Montpellier II, Monpellier, France, 2004.

32. Kouassi, A.M.; Kouamé, K.F.; Goula, B.T.A.; Lasm, T.; Paturel, J.E.; Biémi, J. Influence de la variabilité climatique et de la modification de l'occupation du sol sur la relation pluie-débit à partir d'une modélisation globale du bassin versant du N'zi (Bandama) en Côte d'Ivoire. Revue Ivoirienne. des Sciences et Technologie 2008, 11, 207-229.

33. Tapsobat, D. Caractérisation événementielle des régimes pluviométriques ouest-africains et de leur récent changement. Thèse de Doctorat, Université Paris XI (ORSAY), Paris, France, 1997.

34. Nicholson, S. On the question of the "recovery" of the rains in the West African Sahel. J. Arid Environ. 2005, 63, 615-641. [CrossRef]

35. Mahe, G.; Paturel, J.E. 1896-2006 Sahelian annual rainfall variability and runoff increase of Sahelian Rivers. C.R. Geosci. 2009, 341, 538-546. [CrossRef]

36. Riede, J.O.; Posada, R.; Fink, A.H.; Kaspar, F. What's on the 5th IPCC Report for West Africa? In Adaptation to Climate Change and Variability in Rural West Africa; Springer: Basel, Switzerland, 2016.

37. Haarsma, R.J.; Selten, F.M.; Weber, S.L.; Kliphuis, M. Sahel rainfall variability and response to greenhouse warming. Geophys. Res. Lett. 2005, 32. [CrossRef]

38. Ackerley, D.; Booth, B.B.B.; Knight, S.H.E.; Highwood, E.J.; Frame, D.J.; Allen, M.R.; Rowell, D.P. Sensitivity of twentieth-century sahel rainfall to sulfate aerosol and CO2 forcing. J. Clim. 2011, 24, 499-5014. [CrossRef]

39. Biasutti, M. Forced Sahel rainfall trends in the CMIP5 archive. J. Geophys. Res.: Atmos. 2013, 118, 1613-1623. [CrossRef]

40. Dong, B.W.; Sutton, R. Dominant role of greenhouse gas forcing in the recovery of Sahel rainfall. Nat. Clim. Chang. 2015, 5, 757-760. [CrossRef]

41. Mohino, E.; Janicot, S.; Bader, J. Sahel rainfall and decadal to multi-decadal sea surface temperature variability. Clim. Dyn. 2011, 37, 419-440. [CrossRef]

42. Liebmann, B. A definition for onset and end of the rainy season. 2006. Available online: www.eol.ucar.edu/ projects/cppa/meetings/200608/posters/brant.pdf (accessed on 12 February 2007).

43. WMO. Report on Drought and Countries Affected by Drought during 1974-1985; World Climate Programme 118; World Meteorological Organization: Geneva, Switzerland, 1986.

44. WMO. Statistical distributions for flood frequency analysis. Oper. Hydrol. Rep. 1989, 33. WMO no 718.

45. Dai, A. Increasing drought under global warming in observations and models. Nat. Clim. Chang. 2013, 3, 52-58. [CrossRef]

46. Johns, T.; Gregory, J.; Ingram, W.; Johnson, C.; Jones, A.; Lowe, J.; Mitchell, J.; Roberts, D.; Sexton, D.; Stevenson, D.; et al. Anthropogenic climate change for 1860 to 2100 simulated with the HadCm3 model under updated emissions scenarios. Clim. Dyn. 2003, 20, 583-612.

47. Sylla, M.B.; Giorgi, F.; Coppola, E.; Mariotti, L. Uncertainties in daily rainfall over Africa: Assessment of observation products and evaluation of a regional climate model simulation. Int. J. Climatol. 2013, 33, 1805-1817. [CrossRef]

48. Sylla, M.B.; Dell'Aquila, A.; Ruti, P.M.; Giorgi, F. Simulation of the intraseasonal and the interannual variability of rainfall over West Africa with RegCM3 during the monsoon period. Int. J. Climatol. 2010, 30, 1865-1883. [CrossRef] 
49. Lintner, B.R.; Biasutti, M.; Diffenbaugh, N.S.; Lee, J.E.; Niznik, M.J.; Findell, K.L. Amplification of wet and dry month occurrence over tropical land regions in response to global warming. J. Geophys. Res. 2012, 117, D11106. [CrossRef]

50. Scoccimarro, E.; Gualdi, S.; Bellucci, A.; Zampieri, M.; Navarra, A. Heavy precipitation events In a warmer climate: results from CMIP5 models. J. Clim. 2013, 26, 7902-7911. [CrossRef]

51. Abiodun, B.J.; Lawal, K.A.; Salami, A.T.; Abatan, A.A. Potential influences of global warming on future climate and extreme events in Nigeria. Reg. Environ. Chang. 2013, 477-491. [CrossRef]

52. Giorgi, F.; Coppola, E.; Raffaele, F.; Diro, G.T.; Fuentes-Franco, R.; Giuliani, G.; Mamgain, A.; Llopart, M.P.; Mariotti, L.; Torma, C. Changes in extremes and hydroclimatic regimes in the CREMA ensemble projections. Clim. Chang. 2014, 125, 39-51. [CrossRef]

53. Giorgi, F.; Im, E.S.; Coppola, E.; Diffenbaugh, N.S.; Gao, X.J.; Mariotti, L.; Shi, Y. Higher hydroclimatic intensity with global warming. J. Clim. 2011, 24, 5309-5324. [CrossRef]

54. Sylla, M.B.; Gaye, A.T.; Jenkins, G.S. On the fine-scale topography regulating changes in atmospheric hydrological cycle and extreme rainfall over West Africa in a regional climate model projections. Int. J. Geophys. 2012, 981649. [CrossRef]

55. Sylla, M.B.; Giorgi, F.; Pal, J.S.; Gibba, P.; Kebe, I.; Nikiema, M. Projected changes in the annual cycle of high intensity precipitation events over West Africa for the late 21st century. J. Clim. 2015, 28, 6475-6488. [CrossRef]

(C) 2017 by the authors. Licensee MDPI, Basel, Switzerland. This article is an open access article distributed under the terms and conditions of the Creative Commons Attribution (CC BY) license (http:/ / creativecommons.org/licenses/by/4.0/). 